\title{
Structural characteristics of halobacterial gas vesicles
}

\author{
Sonja Offner, ${ }^{1}$ Ulrike Ziese, ${ }^{2}$ Gerhard Wanner, ${ }^{3}$ Dieter Typke ${ }^{2}$ \\ and Felicitas Pfeifer ${ }^{1}$
}
1 Institut für Mikrobiologie und Genetik, Technische Universităt Darmstadt, Schnittspahnstr. 10, D- 64287 Darmstadt, Germany
2 Max-Planck-Institut für Biochemie, D-82152 Martinsried, Germany
3 Institut für Botanik, Ludwig-Maximilians- Universităt München, D- 80992 Müchen, Germany

\author{
Author for correspondence: Felicitas Pfeifer. Tel: +496151 162957. Fax: +496151 162956. \\ e-mail: Pfeifer@bio.tu-darmstadt.de
}

\begin{abstract}
Gas vesicle formation in halophilic archaea is encoded by a DNA region (the vac region) containing 14 different genes : gvpACNO and gVPDEFGHIJKLM. In Halobacterium salinarum PHH1 (which expresses the p-vac region from plasmid pHH1), gas vesicles are spindle shaped, whereas predominantly cylindrical gas vesicles are synthesized by the chromosomal c-vac region of $\boldsymbol{H}$. salinarum PHH4 and the single chromosomal mc-vac region of Haloferax mediterranei. Homologous complementation of gvp gene clusters derived from the chromosomal c-vac region led to cylindrical gas vesicles in transformants and proved that the activity of the c-gvpA promoter depended on a gene product from the c-gVpE-M DNA region. Heterologous complementation experiments with transcription units of different vac regions demonstrated that the formation of chimeric gas vesicles was possible. Comparison of micrographs of wild-type and chimeric gas vesicles indicated that the shape was not exclusively determined by GupA, the major structural protein of the gas vesicle wall. More likely, a dynamic equilibrium of several gvp gene products was responsible for determination of the shape. Transmission electron microscopy of frozen hydrated, wild-type gas vesicles showed moire patterns due to the superposition of the front and back parts of the ribbed gas vesicle envelope. Comparison of projections of model helices with the moire pattern seen on the cylindrical part of the gas vesicles provided evidence that the ribs formed a helix of low pitch and not a stack of hoops.
\end{abstract}

Keywords: halophilic archaea, gas vesicle structure

\section{INTRODUCTION}

The synthesis of gas vesicles allows micro-organisms to float at a favourable depth in their watery environment. Most of these gas-filled floating devices have cylindrical middle sections with conical caps, and their length varies from 100 to $1500 \mathrm{~nm}$ depending on the microorganism they derive from (for a review see Walsby, 1994). The gas vesicle envelope consists exclusively of protein and is watertight, but freely permeable to dissolved ambient gases. The complete separation and identification of protein components of the gas vesicle

Abbreviations: c-vac, chromosomally located gas vesicle region of Halobacterium salinarum; mc-vac, gas vesicle region located at a single chromosomal position in Haloferax mediterranei; p-vac, gas vesicle region located on plasmid PHH1 of Halobacterium salinarum PHH1; Vac, gas vesicle phenotype. envelope fails because the gas vesicle wall is resistant to conventional biochemical treatments (Krantz \& Ballou, 1973; Simon, 1981). Amino acid sequencing of gas vesicle preparations, immunological analyses and electron microscopy revealed that the hydrophobic $7-8 \mathrm{kDa}$ GvpA protein is the major component of the ribbed gas vesicle envelope (Walker et al., 1984; Surek et al., 1988; Englert et al., 1990), and that the hydrophilic GvpC $(20-42 \mathrm{kDa}$, depending on the species) is a minor constituent of the gas vesicle wall (Walsby \& Hayes, 1988; Hayes et al., 1992; Englert \& Pfeifer, 1993; Halladay et al., 1993). The cyanobacterial GvpC is located at the outer surface of the gas vesicle and strengthens the entire structure (Hayes et al., 1992; Kinsman et al., 1995). The GvpC protein is also responsible for the constant diameter of the cylindrical middle part of the halobacterial gas vesicle (Offner $e t$ al., 1996). If there are other proteins involved in the structure of the gas vesicle, they have yet to be determined. High- 
resolution electron microscopy and atomic-force microscopy of the cyanobacterial gas vesicle envelope indicate that the GvpA protein, forming the $4.6 \mathrm{~nm}$ wide ribs, is arranged as $\beta$-chains and crosses the rib at an angle of $55^{\circ}$ to the rib axis (Blaurock \& Walsby, 1976; McMaster et al., 1996). However, whether the ribs of the gas vesicle are arranged as a helix or as a stack of hoops is still a riddle.

Studies on gas vesicle formation and regulation of the gene products involved have been carried out with a few species of cyanobacteria (Anabaena flos-aquae, Calothrix PCC 7601) and halophilic archaea (Halobacterium salinarum, Haloferax mediterranei, Natronobacterium vacuolatum) (Hayes \& Powell, 1995; Kinsman \& Hayes, 1997; Damerval et al., 1987; Jones et al., 1991; Englert et al., 1992a; Mayr \& Pfeifer, 1997). In the case of the halophilic archaea, transformation experiments confirmed that the 14 different genes clustered in a region (the vac region) of approximately $9 \mathrm{~kb}$ are sufficient for the formation of gas vesicles ( $\mathrm{Vac}^{+}$phenotype) in the $\mathrm{Vac}^{-}$negative recipient, Haloferax volcanii (Blaseio \& Pfeifer, 1990; Englert et al., 1992a, b). Hf. mediterranei contains one chromosomal DNA region (termed mcvac) and $H b$. salinarum $\mathrm{PHH} 1$ harbours two related vac regions: one named p-vac, located on the plasmid pHH1 and the other (c-vac) found in the chromosomal DNA fraction (Horne et al., 1991; Englert et al., 1992a). The genes of all three vac regions are identically arranged: $g \nu p A C N O$ and upstream of $g \nu p A$ but oriented in the opposite direction, $g v p D-M$. Expression of the mc-vac or c-vac region leads to cylindrical gas vesicles in the stationary growth phase only (Englert et al., 1990), whereas the p-vac region encodes predominantly short, spindle-shaped gas vesicles produced during all stages of growth (Horne \& Pfeifer, 1989). The length of the spindle-shaped gas vesicles is fairly constant, around $250 \mathrm{~nm}$, whereas the length of the cylindrical gas vesicles varies between 400 and $1500 \mathrm{~nm}$. The diameter of both specimens varies between 100 and $200 \mathrm{~nm}$ (Stoeckenius \& Kunau, 1968; Simon, 1981; Englert et al., 1990). A peculiarity of the c-vac region is that the c-gvpA promoter is active only in $\mathrm{Hb}$. salinarum strains lacking the plasmid-borne p-vac region (such as $\mathrm{Hb}$. salinarum PHH4), implying a repressor function for one or more of the p-gvp gene products with regard to c-vac expression (Horne et al., 1988).

Analysis of the amino acid sequences of the 14 proteins derived from $g \nu p$ gene sequences indicates that, besides the two structural proteins GvpA and GvpC, other proteins might be minor components of the gas vesicle envelope: GvpJ (10-12 kDa) and GvpM (8-9 kDa) share sequence and structural similarity with the GvpA protein (Englert et al., 1992a). As these proteins are encoded by the early-transcribed $g \nu p F-M$ genes, they might participate in an early stage of gas vesicle assembly. The small GvpG (10 kDa) and GvpK (12.7 $\mathrm{kDa})$ proteins have a hydrophobic $\mathrm{N}$-terminal part and a hydrophilic C-terminus (Englert et al., 1992a), which could function either as structural components of the gas vesicle or as a kind of chaperone, aiding solubilization of the hydrophobic GvpA, GvpJ and GvpM monomers in the cytoplasm.

The transformation system for halobacteria permits functional analysis of the gvp genes in gas vesicle synthesis. Shuttle vectors are available that harbour genes conferring resistance to mevinolin (Lam \& Doolittle, 1989; Blaseio \& Pfeifer, 1990) or novobiocin (Holmes et al., 1991), and compatible origins of replication. The vectors used for complementation studies with the $\mathrm{Vac}^{-}$recipient $H f$. volcanii also include an expression vector which enables high-level expression of halobacterial genes under the control of the strong promoter of the halobacterial ferredoxin $(f d x)$ gene (Pfeifer et al., 1994). Previous transformation experiments showed that (i) the p-vac as well as the mc-vac region present on a single vector leads to gas vesicle formation in Hf. volcanii (Blaseio \& Pfeifer, 1990; Englert $e t$ al., 1992a) and (ii) complementation of the pg $\nu p A C N O$ and p-g $\nu p D-M$ transcription units is possible in transformants, allowing the synthesis of mainly spindle-shaped gas vesicles (Offner \& Pfeifer, 1995).

Here we report transformation experiments designed to uncover the $g \nu p$ gene products involved in the determination of the different gas vesicle shapes (spindle shaped or cylindrical). Transformants were analysed by Western blots to observe the synthesis of GvpA, and the shape of isolated gas vesicles was inspected by electron microscopy. In addition, transmission electron microscopy of frozen hydrated samples of intact gas vesicles was carried out to gain insights into the microstructure of the gas vesicle wall.

\section{METHODS}

Strains and growth conditions. E. coli strains DH5 $\alpha$ (Hanahan, 1983) and GM1674 (dam) (Palmer \& Marinus, 1994) were grown aerobically at $37^{\circ} \mathrm{C}$ in LB broth (Sambrook et al., 1989) with ampicillin at a concentration of $100 \mu \mathrm{g} \mathrm{ml}^{-1}$. Hb. salinarum PHH1 [renamed by Ventosa \& Oren (1996); formerly $\mathrm{Hb}$. halobium or $\mathrm{Hb}$. salinarium] was grown in rich medium containing $\left(\mathrm{l}^{-1}\right): 245.4 \mathrm{~g} \mathrm{NaCl} ; 20 \mathrm{~g} \mathrm{MgSO}_{4} .7 \mathrm{H}_{2} \mathrm{O}$; $2 \mathrm{~g} \mathrm{KCl} ; 50 \mathrm{ml} 1 \mathrm{M}$ Tris/ $\mathrm{HCl} \mathrm{pH} 7 \cdot 2 ; 2 \mathrm{ml} 10 \% \mathrm{CaCl}_{2} \cdot 2 \mathrm{H}_{2} \mathrm{O}$ and $15 \mathrm{~g}$ Oxoid peptone. Hf. volcanii WFD11, lacking the endogenous plasmid pHV2 (Cline et al., 1989), was grown in rich medium containing $\left(1^{-1}\right): 175 \mathrm{~g} \mathrm{NaCl} ; 37 \mathrm{~g}$ $\mathrm{MgSO}_{4} .7 \mathrm{H}_{2} \mathrm{O} ; 3.7 \mathrm{~g} \mathrm{KCl} ; 5 \mathrm{~g}$ Bacto tryptone; $3 \mathrm{~g}$ Bacto yeast

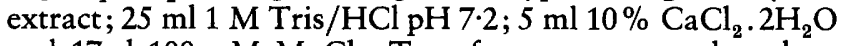
and $17 \mu \mathrm{l} 100 \mathrm{mM} \mathrm{MnCl}$. Transformants were selected on agar plates containing $0.2 \mu \mathrm{g}$ novobiocin $\mathrm{ml}^{-1}$ and $6 \mu \mathrm{g}$ mevinolin $\mathrm{ml}^{-1}$. Lovastatin (mevinolin) was a gift from Merck, Sharpe \& Dohme (München).

Constructs used for transformation of $\mathrm{Hf}$, volcanii and transformation procedure. Subfragments of the p-vac region used to construct plasmids are listed in Table 1 and Fig. 1. In most cases, the DNA inserts (cE-M, cA-OI, mcD-M, mcA-O, mcA) were blunt-end ligated to the halobacterial vectors pMDS20 (blunt-ended ligation into the filled-in HindIII site), pWL102 (blunt-ended ligation into the filled-in BamHI site), or the SmaI site of pUBP2 (Holmes et al., 1991; Lam \& Doolittle, 1989; Blaseio \& Pfeifer, 1990).

The construction of the $\mathrm{pD}-\mathrm{M}, \mathrm{pA}-\mathrm{O}$ and $\mathrm{p} \Delta \mathrm{A}$ fragments are 
Table 1. DNA subfragments of the p-vac, the c-vac and the mc-vac region used for transformation

The accession numbers of the p-vac sequence in the EMBL database are: X55684 for p-gvpD-M, and $\mathrm{X} 64729$ for $\mathrm{p}-\mathrm{g} \nu \mathrm{p} A C \mathrm{NO}$. The EMBL accession number for the c-vac region is $\mathrm{X} 94688$.

\begin{tabular}{|lccc|}
\hline $\begin{array}{l}\text { Fragment } \\
\text { name* }\end{array}$ & Restriction site & Position $\dagger$ & Size (bp) \\
\hline pD-M & & & \\
pA-O & EcoRI-XcmI & $294-6518$ & 6224 \\
p $\Delta A$ & HindIII-BglII & $6399-9771$ & 3373 \\
cE-M & MroI-SspI $\langle\Delta X c m I-S t u I)$ & $1-9921(\Delta 6518-6761)$ & $9920(\Delta 243)$ \\
cA-OI & NruI-NruI & approx. 250-4679 & approx. 4930 \\
cA-OII & $S s p I-B a m$ HI & $6032-8929$ & 2897 \\
cAII & - & $6206-8878$ & 2672 \\
mcD-M & - & $6206-6450$ & 244 \\
mcA-O & $X c m I-S c a I$ & $4104-11247$ & 7143 \\
mcA & $X b o I-S c a I$ & $4660-419$ & 4241 \\
\hline
\end{tabular}

* The first letter of the fragment name ('p', ' $c$ ', or ' $m c$ ') indicates the vac region (p-vac, c-vac, or mcvac) it derives from. The Roman numerals (I, II) in the name of the $\mathrm{cA}-\mathrm{O}$ and the cA fragment differentiate the two constructs, which contain the same gvp genes, but have different fragment lengths.

$\dagger$ The position of the restriction sites of the p-vac region is given starting from the MroI site (position 1) located $491 \mathrm{nt}$ downstream of the p-gvpM gene through to the ISH2 element located downstream of p-g $v p \mathrm{O}$ in pHH1 (see Fig. 1). The start of the ISH2 element is at position 9842 . The internal deletion in the $\Delta \mathrm{A}$ construct is given in parentheses. Position 1 of the $\mathrm{c}$-vac region is represented by the PstI site located $435 \mathrm{bp}$ downstream of the stop codon of the c-gvpM gene. Position 1 of the mc-vac region corresponds to the PstI site lying $1157 \mathrm{bp}$ downstream of the mc-gvpO gene.

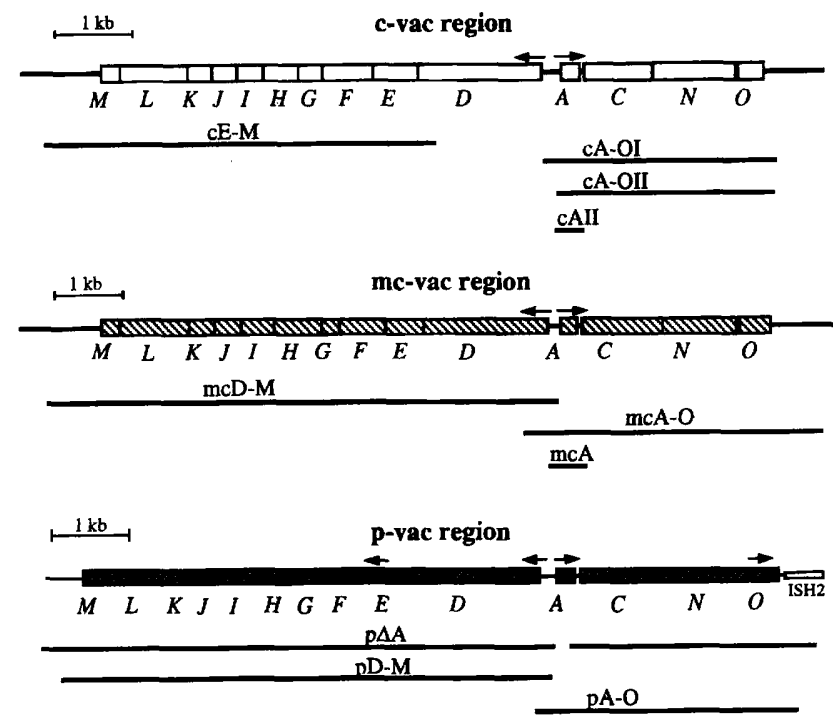

Fig. 1. Subfragments of the three vac regions used for transformation experiments. The physical map of each vac region indicates the gvpD-M and gvpACNO genes as boxes. Arrows mark the start and direction of the transcripts. The subfragments used for the transformation experiments (see Table 1) are indicated by lines below the boxes. The designation of subfragments is according to the gvp genes present near the boundary, except for $p \Delta A$, which corresponds to the whole $p$-vac region, but lacking the $p-g v p A$ gene. Analysis of the $\mathrm{pD}-\mathrm{M} / \mathrm{pA}-\mathrm{O}$ transformant has already been published (Offner \& Pfeifer, 1995). described by Offner \& Pfeifer (1995) and the cAII construct is published by Pfeifer et al. (1994).

The cA-OII DNA fragment was amplified by PCR using the oligonucleotides 5'-AGATCACCATGGCGCAACCAGACTC-3' and 5'-CCGACCATGGTGACCTGCATCACTGTCGCG-3' (NcoI sites underlined). The PCR product was cut by $\mathrm{NcoI}$ and ligated to the $\mathrm{NcoI}$-cleaved expression vector pJAS35 (Pfeifer et al., 1994).

Prior to transformation of Hf. volcanii, each construct was passaged through the E. coli dam strain GM1674 to avoid a halobacterial restriction barrier (Holmes et al., 1991). Transformation was as described by Pfeifer \& Ghahraman (1993). Southern analyses of total DNA of the transformants using a vac-region-specific DNA probe (digoxigenin-labelled; kit from Boehringer Mannheim) determined the presence of the desired plasmids.

Immunological detection of the GvpA protein. Proteins of halobacteria were isolated from a $5 \mathrm{ml}$ culture in early stationary phase. Pelleted cells were resuspended in $0.4 \mathrm{ml} \mathrm{TE}$ buffer containing $10 \mu \mathrm{g}$ DNase $\mathrm{I} \mathrm{ml}^{-1}$. The suspension was dialysed against $10 \mathrm{mM}$ Tris/ $\mathrm{HCl}, \mathrm{pH} 7.2$ overnight and centrifuged for $20 \mathrm{~min}$ at $12000 \mathrm{~g}$ for membrane removal. Proteins $(20 \mu \mathrm{g}$ each) were separated on $12 \%$ Tricine-SDSpolyacrylamide gels, according to Schägger \& von Jagow (1987). Western analyses were performed as previously described (Englert et al., 1992b) using an antiserum raised against gas vesicles of $H f$. mediterranei; this exclusively detects the GvpA protein.

Isolation of gas vesicles and examination by electron microscopy. Hf. volcanii transformants were grown on agar 
plates for 1-2 weeks. Stationary-phase cells were scraped from the agar and lysed in $10 \mathrm{mM}$ Tris/ $\mathrm{HCl}, \mathrm{pH} \mathrm{7.2,} \mathrm{with} 1-2 \mu \mathrm{l}$ DNase I $\left(1 \mathrm{mg} \mathrm{m}^{-1}\right)$. Gas vesicles were collected by accelerated flotation in small narrow tubes (diameter $4 \mathrm{~mm}$ ) by centrifugation in an Eppendorf centrifuge for $20 \mathrm{~min}$ at 1000-2000 r.p.m. and were washed three times with $10 \mathrm{mM}$ Tris $/ \mathrm{HCl}, \mathrm{pH} 7 \cdot 2$. For negative staining, a drop of the gas vesicle preparation was placed on a carbon-coated copper grid, removed after 2 min with a pipette and air dried. Gas vesicles were treated for $1 \mathrm{~min}$ with a solution of $1 \%$ uranyl acetate and $0.01 \%$ glucose in water, briefly rinsed with a drop of water and then air dried. The specimens were examined with a Zeiss EM 912 transmission electron microscope operated with the OMEGA energy filter in the zero loss mode.

Electron microscopy and image processing of frozen hydrated gas vesicles. Frozen hydrated samples of gas vesicles of Hb. salinarum $\mathrm{PHH} 1$ were prepared for cryo-electron microscopy by fast-freezing thin films of sample solution on grids covered with a holey carbon film in liquid ethane with a gravity-driven plunger. Specimens were observed using a Gatan cryoholder in a Philips CM12 electron microscope equipped with a Gatan imaging filter. Images were recorded using a slow-scan CCD camera attached to the microscope. The microscope was operated at $80 \mathrm{kV}$ accelerating voltage and $56900 \times$ total magnification on the CCD camera. The calibrated CCD pixel size referring to the specimen level was $0.42 \mathrm{~nm}$.

Image processing, including image enhancement and helical simulations, was performed on a Silicon Graphics Indigo ${ }^{2}$ workstation, using the EM program package (Hegerl, 1996). For image enhancement, areas of the original images were window-filtered using the strongest reflections of their power spectra. For better visibility, the image contrast was reversed; thus protein appears lighter than the surrounding ice. For simulations, three-dimensional maps of helices or rings, with different ratios of the diameter of the helix of the ring to the distance of helical turns or rings, were created and projected at different angles.

\section{RESULTS}

\section{Formation of chimeric gas vesicles using heterologous gvp gene clusters}

Homologous complementation with subfragments of the c-vac region. Initial transformation experiments were performed to test whether the gup gene products of the c-vac region were sufficient to synthesize gas vesicles in transformants. For this purpose, $H f$. volcanii was transformed with the $\mathrm{cE}-\mathrm{M}$ and the $\mathrm{cA}-\mathrm{OI}$ constructs (Table 1, Fig. 1). The cE-M construct lacked the c-gvpD gene and the native promoter for the c-gvpD-M transcription unit. However, c-gvpE-M were transcribed from a fortuitous promoter sequence of the vector, as demonstrated by primer extension (Krüger, 1996).

The $\mathrm{cE}-\mathrm{M} / \mathrm{cA}-\mathrm{OI}$ double transformant synthesized gas vesicles (Table 2), demonstrating that (i) complementation of the $c-g \nu p E-M$ and the $c-g \nu p A C N O$ genes led to gas vesicle formation in transformants, and (ii) as in the p-vac region (Offner \& Pfeifer, 1995), the c-gvpD gene was not essential for the synthesis of gas vesicles. The $c E-M / c A-O I$ double transformant was investigated by Western analyses using an antiserum specifi-
Table 2. Constructs used for transformation experiments, presence of GvpA and gas vesicle phenotype

\begin{tabular}{|c|c|c|c|}
\hline \multicolumn{2}{|c|}{ Construct* } & \multirow[b]{2}{*}{ GvpAg } & \multirow[b]{2}{*}{ Vac\# } \\
\hline 1 & 2 & & \\
\hline $\mathrm{pA}-\mathrm{O} \dagger$ & $\mathrm{pD}-\mathrm{MS}$ & + & $++\dagger$ \\
\hline $\mathrm{cA}-\mathrm{OI} \dagger$ & $\mathrm{cE}-\mathrm{M} \$ & + & $+t \dagger$ \\
\hline $\mathrm{cA}-\mathrm{OI} \dagger$ & - & - & - \\
\hline cA-OII $\neq$ & - & $+\left(\mathrm{c}-\mathrm{GvpA}_{\mathrm{mut}}\right)$ & - \\
\hline cA-OII $\ddagger$ & $\mathrm{cE}-\mathrm{M} \S$ & $+\left(c-G v p A_{\text {mut }}\right)$ & - \\
\hline $\mathrm{pA}-\mathrm{O}+$ & $\mathrm{cE}-\mathrm{MS}$ & + & + \\
\hline cA-OII $\neq$ & $\mathrm{pD}-\mathrm{M} \$$ & $+\left(\mathrm{c}-\mathrm{GvpA}_{\mathrm{mut}}\right)$ & - \\
\hline cAII $\neq$ & $\mathrm{p} \Delta \mathrm{A} \|$ & $+\left(c-G v p A_{m u t}\right)$ & $+t+$ \\
\hline cA-OI $\ddagger$ & $\mathrm{pD}-\mathrm{MS}$ & - & - \\
\hline mcAt & - & + & - \\
\hline $\mathrm{mcA}-\mathrm{O}+$ & $\mathrm{mcD}-\mathrm{MS}$ & + & + \\
\hline $\mathrm{mcA}-\mathrm{O}+$ & $\mathrm{pD}-\mathrm{M} \$ & + & $+t+$ \\
\hline $\mathrm{pA}-\mathrm{O} \dagger$ & $\mathrm{mcD}-\mathrm{M} s$ & + & $+\dagger \dagger$ \\
\hline mcAt & $\mathrm{p} \Delta \mathrm{A} S$ & + & + \\
\hline
\end{tabular}

* The name of the construct used for transformation is given in capital letters and indicates the respective gvp gene cluster according to Fig. 1 (also see Table 1). The vectors used are: $\dagger$, pMDS20; ‡, pJAS35; \&, pUBP2; \|, pWL102.

I The GvpA protein was assigned by Western analyses.

\# The presence of gas vesicles in the cells was determined by phase-contrast microscopy.

†† $\mathrm{Vac}^{+}$transformants from which gas vesicles could be isolated.

cally detecting the GrpA protein of the three vac regions (Englert et al., 1992b), and it exhibited a faint c-GvpAspecific signal (Fig. 2a). Surprisingly, a transformant containing the $\mathrm{cA}-\mathrm{OI}$ construct by itself lacked the cGvpA protein (Fig. 2a), indicating an inactive c-gvpA promoter in this transformant. As the $c E-M / c A-O I$ transformant synthesized c-GvpA, a gene product of the c-gvpE-M genes was postulated to serve as an activator that directly or indirectly (by repressing the action of a repressor) activates the c-gvpA promoter. Subsequently, the $\mathrm{c}-\mathrm{GvpE}$ protein was identified as the transcriptional activator of the c-gvpA promoter (Krüger \& Pfeifer, 1996).

Heterologous complementation with subfragments of the c-vac and p-vac region. To determine whether heterologous complementations are possible and lead to chimeric gas vesicles, the $g \nu p A C N O$ and $g \nu p D-M$ transcription units of the $c$-vac and p-vac regions were used for transformation experiments in both combinations $(\mathrm{pD}-\mathrm{M} / \mathrm{cA}-\mathrm{OI}$, cE-M/pA-O; Table 1, Fig. 1). Previous studies showed that the $\mathrm{p}-g \nu p A$ promoter did not need activation by another gene product and that the $\mathrm{pD}-\mathrm{M} / \mathrm{pA}-\mathrm{O}$ transformant synthesized spindle-shaped gas vesicles (Table 2, Offner \& Pfeifer, 1995).

Heterologous complementation of the $\mathrm{cE}-\mathrm{M}$ and $\mathrm{pA}-\mathrm{O}$ constructs allowed the synthesis of chimeric gas vesicles in double transformants as determined by phase-con- 


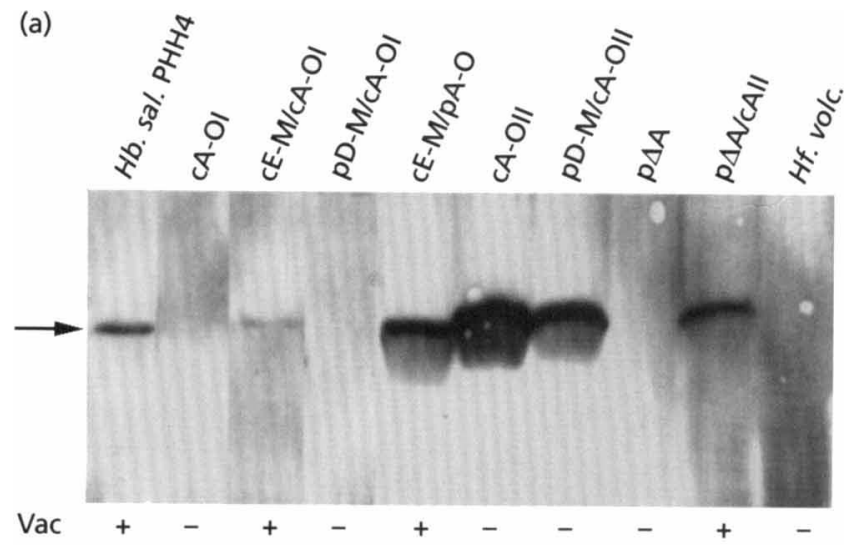

(b)

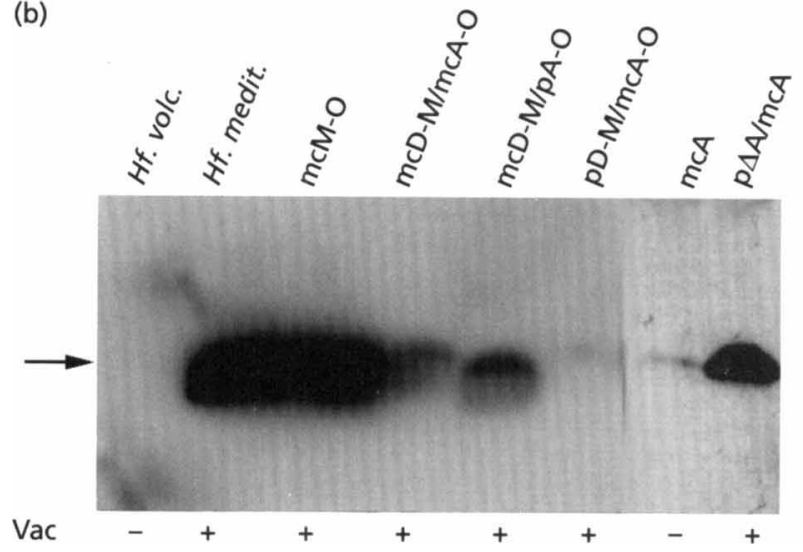

Fig. 2. Western analyses to determine the presence of GvpA in samples of the transformants, $H b$. salinarum PHH4, $H f$. mediterranei and $\mathrm{Hf}$. volcanii. The proteins ( $20 \mu \mathrm{g}$ per lane) were separated on $12 \%$ tricine-SDS-polyacrylamide gels, transferred to nitrocellulose membranes and incubated with the anti-gas-vesicle serum as described by Englert et al. (1992b). Transformants and constructs are described in Table 2 and Fig. 1. The reacting GvpA protein is indicated by an arrow. The faint signal of the GvpA protein of the $\mathrm{PD}-\mathrm{M} / \mathrm{mCA}-\mathrm{O}$ transformant in (b) is better visible on the original autoradiogram. The gas vesicle phenotype ( $\mathrm{Vac}$ ) is indicated by plus or minus.

trast microscopy (Table 2). Unfortunately, the number of chimeric gas vesicles produced was so low that it was impossible to isolate them and determine their shape by electron microscopy. In contrast, the $\mathrm{pD}-\mathrm{M} / \mathrm{cA}-\mathrm{OI}$ transformant did not synthesize gas vesicles (Table 2). Western analysis demonstrated that this transformant lacked c-g $v p A$ expression, implying that the p-g $\nu p D-M$ gene products failed to activate the $c-g \nu p A$ promoter (Fig. 2a). Consequently, the absence of gas vesicle synthesis by the $\mathrm{pD}-\mathrm{M} / \mathrm{cA}-\mathrm{OI}$ transformant could be attributed to lack of c-gupACNO expression.

To bypass the lack of the c-GvpA protein in the $\mathrm{pD}-\mathrm{M} / \mathrm{cA}-\mathrm{OI}$ transformant, the halobacterial expression vector was used to force c-gvpACNO expression. Briefly, the ATG start codon of the desired reading frame was inserted into the $\mathrm{NcoI}$ site downstream of the ferredoxin $(f d x)$ promoter in the expression vector, leading to a gene product with two additional amino acids (Met, Pro) at the N-terminus (Pfeifer et al., 1994). The resulting construct, termed cA-OII, was used for transformation of $H f$. volcanii. As expected, Western analysis of the cA-OII transformant indicated the presence of a large amount of c-GvpA with slightly higher molecular mass due to the two additional amino acids (c-GvpA mut $_{\text {) }}$ (Fig. 2a). However, homologous complementation of the cA-OII construct with the cE-M construct revealed a $\mathrm{Vac}^{-}$phenotype for the $\mathrm{cE}-\mathrm{M} / \mathrm{cA}-\mathrm{OII}$ transformant (Table 2), implying that the two additional amino acids at the $\mathrm{N}$-terminus of c$\mathrm{GvpA}_{\text {mut }}$ prevented the formation of gas vesicles. Also, the $\mathrm{pD}-\mathrm{M} / \mathrm{cA}-\mathrm{OII}$ transformant was $\mathrm{Vac}^{-}$, despite the presence of the c-GvpA mut protein (Table 2; Fig. 2a). These results suggest that the $c-G v p A_{\text {mut }}$ protein was incompatible with the $\mathrm{p}-g \nu p D-M$ or the remaining cgup gene products.

As the $\mathrm{p} \Delta \mathrm{A}$ construct, containing the entire $\mathrm{p}$-vac region except for the p-g $\nu p A$ gene (Offner \& Pfeifer, 1995), and the cAII construct, expressing the $c-G_{v p A}$ mut protein (Pfeifer et al., 1994), were available (Table 1; Fig. 1) the $\mathrm{cAII} / \mathrm{p} \Delta \mathrm{A}$ double transformant was tested for gas vesicle production. Indeed, the phenotype of this transformant was $\mathrm{Vac}^{+}$, suggesting that the $\mathrm{c}-\mathrm{GvpA}_{\text {mut }}$ protein and the p-gvp gene products are compatible and lead to chimeric gas vesicles in transformants (Table 2). This result implied that the $c-G v p A_{\text {mut }}$ protein was not compatible with one or more gene products of cgupCNO, because these genes constituted the only difference between the $\mathrm{Vac}^{-} \mathrm{cA}-\mathrm{OII} / \mathrm{pD}-\mathrm{M}$ transformant and the $\mathrm{Vac}^{+} \mathrm{cAII} / \mathrm{p} \Delta \mathrm{A}$ transformant. The chimeric gas vesicles of the $\mathrm{cAII} / \mathrm{p} \Delta \mathrm{A}$ transformant were isolated and examined by electron microscopy (see below).

In summary, the formation of chimeric p-vac/c-vac gas vesicles by heterologous complementation experiment was hampered by regulatory or structural incompatibilities as described above. Therefore, subfragments of the mc-vac region were used in similar complementation experiments.

Complementation studies with subfragments of the mc-vac and $p$-vac region. Previous studies demonstrated that the mc-vac region leads to gas vesicle formation in transformants (Blaseio \& Pfeifer, 1990; Englert et al., 1992a). The $\mathrm{mcD}-\mathrm{M}$, the $\mathrm{mcA}-\mathrm{O}$ and the mcA construct were generated and used for homologous and heterologous complementation studies (Table 1, Fig. 1). The mcD$\mathrm{M} / \mathrm{mcA}-\mathrm{O}$ double transformant harbouring the mc$g \nu p A C N O$ and mc-g $v p D-M$ transcription units on separate vectors was $\mathrm{Vac}^{+}$, and Western analysis indicated the presence of the mc-GvpA protein (Table 2, Fig. $2 b)$. Similar Western analysis of the mcA transformant showed a faint signal of the mc-GvpA protein (Fig. 2b), indicating that the mc-gvpA gene expression was leaky (Englert et al., 1992b; Röder \& Pfeifer, 1996). As minimal mc-g $\nu p A$ expression appeared in the $\mathrm{mcA}$ transformant, the $\mathrm{mcA}, \mathrm{mcA}-\mathrm{O}$ and $\mathrm{mcD}-\mathrm{M}$ constructs were used for heterologous complementation experi- 
Hb. salinarum $\mathrm{PHH} 1$

p-vac

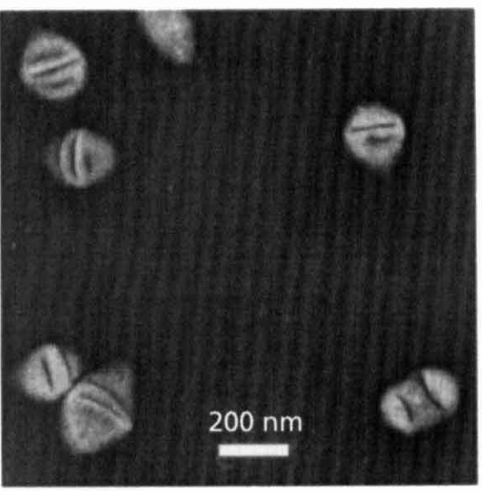

$\mathrm{p} \Delta \mathrm{A} / \mathrm{cAll}$

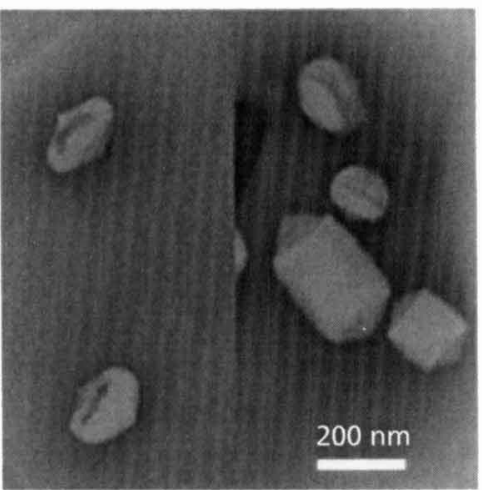

Hf. volcanii transformants

Hb. salinarum $\mathrm{PHH} 4$

c-vac

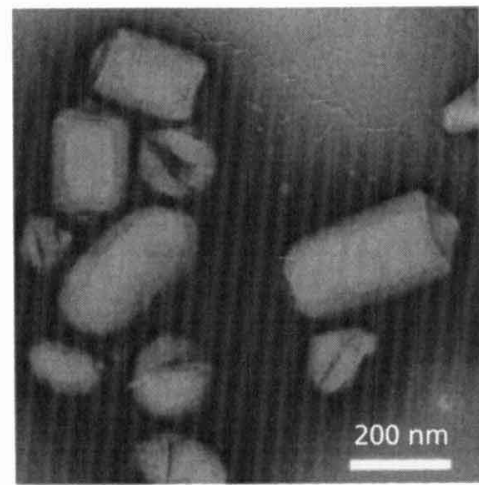

$\mathrm{mcD}-\mathrm{M} / \mathrm{pA}-\mathrm{O}$

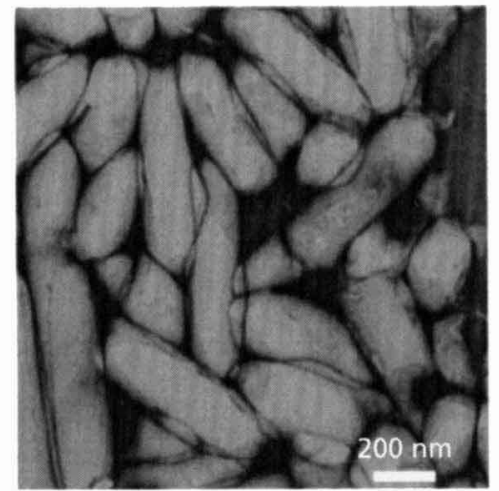

Hb. mediterranei

mc-vac

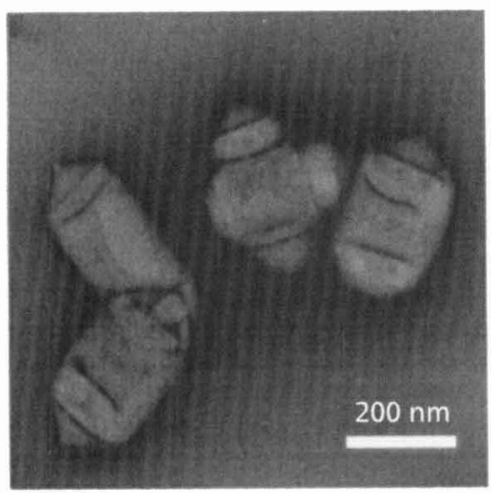

Fig. 3. Electron micrographs of isolated gas vesicles. Upper row: gas vesicles of $H b$. salinarum $\mathrm{PHH} 1, \mathrm{Hb}$. salinarum $\mathrm{PHH} 4$ and $\mathrm{Hf}$. mediterranei. Lower row: chimeric gas vesicles of $\mathrm{Hf}$. volcanii transformants containing heterologous gvp gene clusters.

ments with subfragments of the p-vac region. Double transformants were generated in both combinations: $\mathrm{pD}-\mathrm{M} / \mathrm{mcA}-\mathrm{O}$ and $\mathrm{mcD}-\mathrm{M} / \mathrm{pA}-\mathrm{O}$ (Table 2 ). In both cases, the transformants were $\mathrm{Vac}^{+}$, and Western analyses confirmed the presence of the GvpA protein (Fig. 2b). Isolated chimeric gas vesicles were used for investigation by electron microscopy (see below).

In addition, the $\mathrm{p} \Delta \mathrm{A}$ transformant was complemented with the mcA construct (Table 2). As shown by Western analyses, a larger amount of the mc-GvpA protein was present in the $\mathrm{p} \Delta \mathrm{A} / \mathrm{mcA}$ transformant than in the $\mathrm{mcA}$ transformant (Fig. 2b), indicating activation of the mc$g \nu p A$ promoter by a gene product of the p-vac region. The $\mathrm{p} \Delta \mathrm{A} / \mathrm{mcA}$ transformant also synthesized gas vesicles, but at a very low level which was insufficient to permit isolation of these chimeric gas vesicles for electron microscopic studies.

Analysis of wild-type and chimeric gas vesicles by electron microscopy. Gas vesicle preparations of halobacterial species and of $\mathrm{Vac}^{+}$transformants were examined by electron microscopy. The shape of the gas vesicles seen in electron micrographs was correlated with the genotype of the respective micro-organism in order to identify the transcription unit harbouring the genetic determinants responsible for gas vesicle shape. In general, a cylindrical gas vesicle shape depends on the presence of a cylindrical middle section with constant diameter. Absence of this in spindle-shaped gas vesicles causes a difference in length. As the diameter of gas vesicles varies regardless of their shape, only the length was used for characterizing the gas vesicle shape.

Electron micrographs of wild-type gas vesicles showed that $95 \%$ of the gas vesicles from $\mathrm{Hb}$. salinarum $\mathrm{PHH} 1$ are spindle shaped, with a mean length of $280 \mathrm{~nm}$ (Stoeckenius \& Kunau, 1968; Englert et al., 1990). In contrast, $\mathrm{H} b$. salinarum $\mathrm{PHH} 4$ and $\mathrm{Hf}$. mediterranei synthesize predominantly cylindrical gas vesicles, with mean lengths of $347 \mathrm{~nm}$ and $455 \mathrm{~nm}$, respectively (Fig. $3)$. Transformants containing gvp genes of the p-vac region $(\mathrm{pD}-\mathrm{M} / \mathrm{pA}-\mathrm{O})$ are spindle shaped (Offner \& 


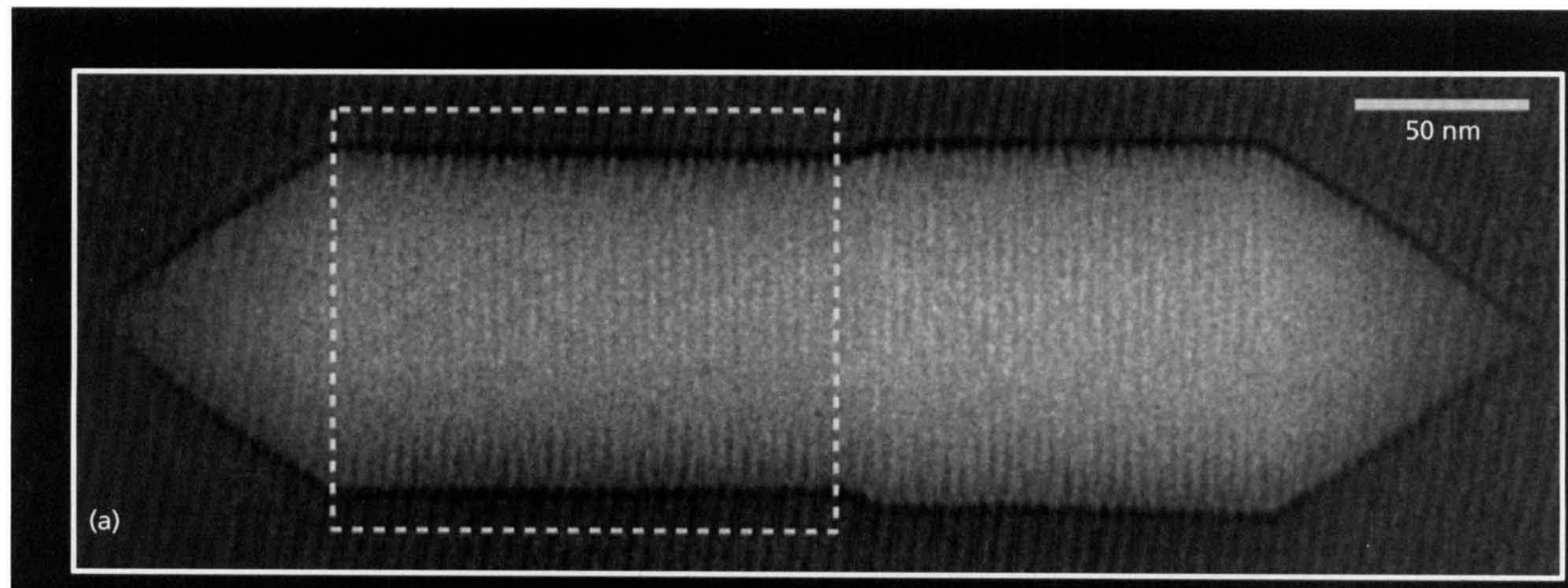

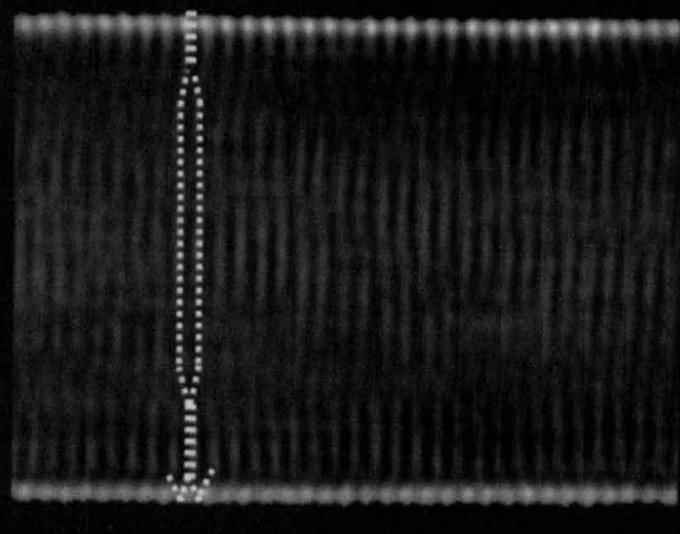

(b)

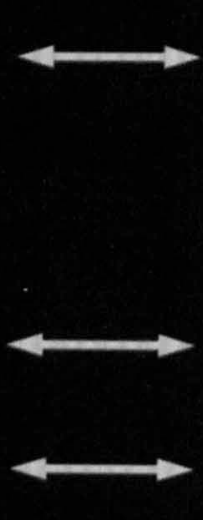

$30 \mathrm{~nm}$

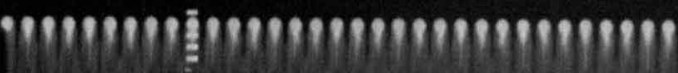

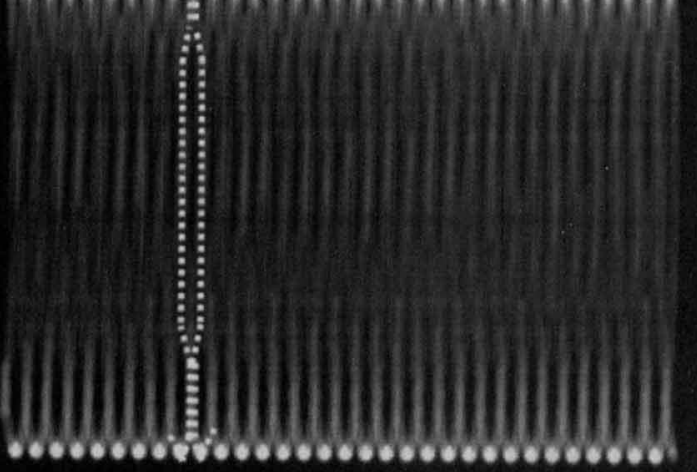

(c)

Fig. 4. (a) Electron micrograph of a frozen hydrated gas vesicle of $H b$. salinarum PHH1. Protein is darker than the surrounding ice due to its stronger scattering of electrons. The dashed box encloses the region magnified in (b). (b) Magnified part of (a) after image enhancement and contrast reversal; thus, the protein appears lighter than the surrounding ice. (c) Model helix, with a value of 22.6 for the ratio of the diameter of the model to the distance of the ribs, projected at an angle of $88.1^{\circ}$ against the helical axis. In (b) and (c) the arrows indicate the position of the extinction stripes in the moiré patterns; the dashed lines correspond to the position of the projection of one full helical turn.

Pfeifer, 1995), whereas transformants containing the $\mathrm{c}-\mathrm{vac}$ (cE-M/cA-OI), or mc-vac region (mcM-O) synthesized predominantly cylindrical gas vesicles (Englert et. al., 1992b and data not shown).

Only with the p $\Delta \mathrm{A} / \mathrm{cAII}$ ( $\mathrm{c}-\mathrm{Gvp} \mathrm{A}_{\text {mut }}$ ), $\mathrm{pD}-\mathrm{M} / \mathrm{mcA}-\mathrm{O}$ and $\mathrm{mcD}-\mathrm{M} / \mathrm{pA}-\mathrm{O}$ transformants were chimeric gas vesicles obtained in sufficient amounts to be isolated for electron microscopy (Fig. 3). Measurement of length and determination of shape gave the following results. Spindle-shaped gas vesicles, with a length of $157 \mathrm{~nm}$ or $235 \mathrm{~nm}$ were synthesized in a significant proportion $\langle 50 \%$ ) only by the $\mathrm{p} \Delta \mathrm{A} / \mathrm{cAII}$ and the $\mathrm{pD}-\mathrm{M} / \mathrm{mcA}-\mathrm{O}$ transformant, respectively. The cylindrical gas vesicles of the two transformants had a mean length of about $325 \mathrm{~nm}$ and $573 \mathrm{~nm}$, respectively (Fig. 3). Obviously, the addition of two amino acids in the $\mathrm{c}-\mathrm{GvpA}_{\text {mut }}$ protein of the $\mathrm{p} \Delta \mathrm{A} / \mathrm{cAII}$ transformant did not hinder the formation of $50 \%$ spindle-shaped gas vesicles, but these were slightly shorter and wider than wild-type gas vesicles (Fig. 3). In contrast, gas vesicles of the mcD-M/pA-O transformant were exclusively cylindrical, with a mean length of $640 \mathrm{~nm}$ (Fig. 3). Since the $\mathrm{pD}-\mathrm{M} / \mathrm{mcA}-\mathrm{O}$ transformant contained a significant proportion of spindle-shaped gas vesicles, the g $v p$ genes involved in the formation of the spindle shape are localized in the $\mathrm{p}$ $g v p D-M$ DNA region and not in the $\mathrm{p}-g \nu p A C N O$ gene cluster. The mc-GvpA protein constituted the cylindrical and spindle-shaped gas vesicles in the $\mathrm{pD}-\mathrm{M} / \mathrm{mcA}-\mathrm{O}$ transformant, whereas the $\mathrm{p}-\mathrm{GvpA}$ protein formed the cylindrical gas vesicles of the $\mathrm{mcD}-\mathrm{M} / \mathrm{pA}-\mathrm{O}$ transformant. 


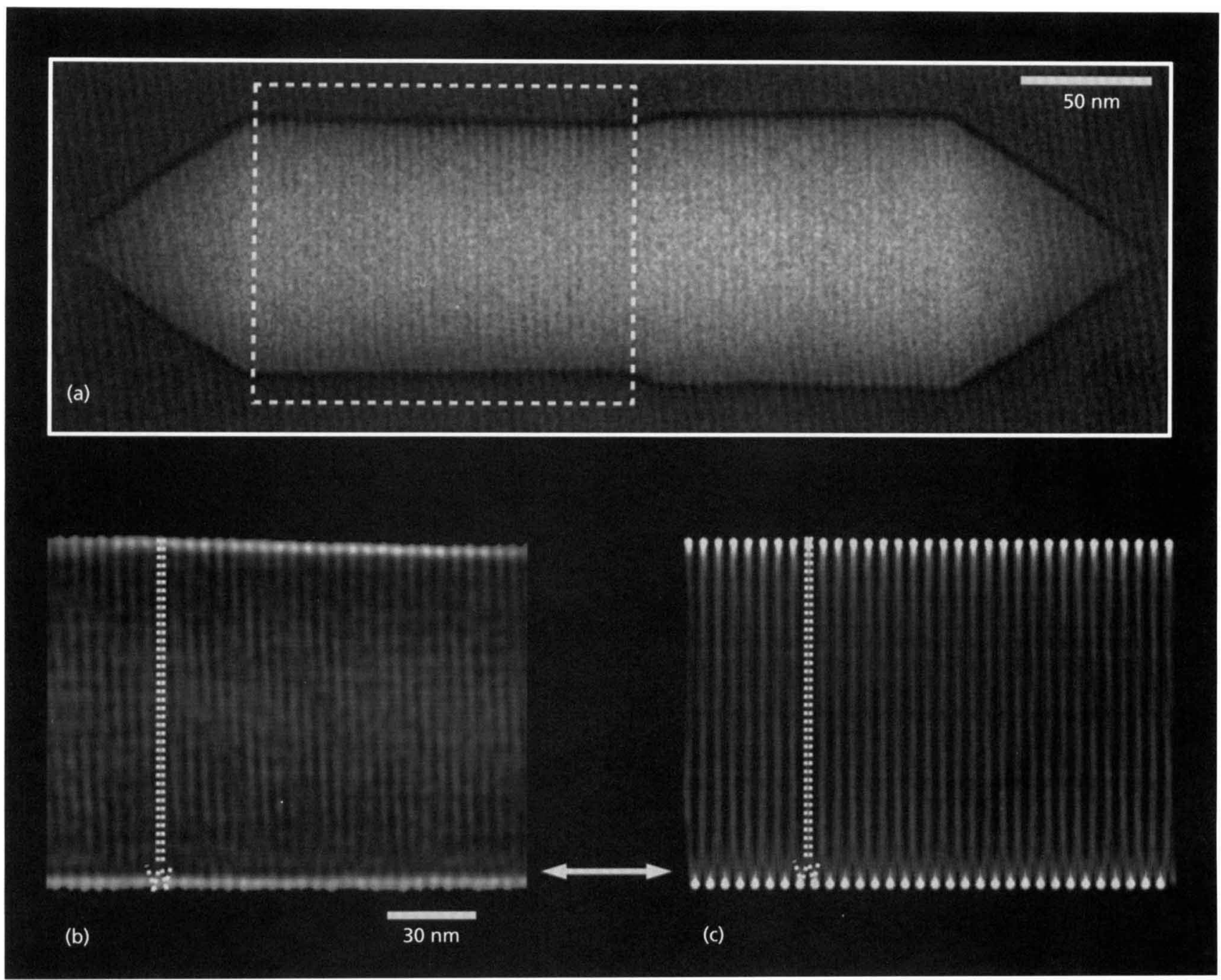

Fig. 5. (a) Electron micrograph of a second image of the same gas vesicle shown in Fig. 4 , but tilted by $5^{\circ}$ relative to it. The dashed box indicates the region magnified in (b). (b) Magnified part of (a) after image enhancement and contrast reversal. (c) Same model helix as in Fig. 4(c), projected at an angle of $87.0^{\circ}$.

\section{Analysis of the microstructure of the gas vesicle wall by transmission electron microscopy and model calculations}

Electron microscopy and image processing of frozen hydrated gas vesicles. A gas vesicle preparation of $H b$. salinarum $\mathrm{PHH} 1$ was investigated in a frozen hydrated state, which is supposed to yield the best structural preservation for proteins. Figs $4(a)$ and 5(a) show two projections of the same intact, gas-filled gas vesicle, which was used in this investigation; the sample in the second image was tilted by $5^{\circ}$ relative to the first one. The tilt-axis was almost parallel to the long axis of the gas vesicle. The gas vesicle was cylindrical, with a small change in diameter in the middle of the particle, and had conical ends. The contrast of the images originated from the density differences between the proteinaceous gas vesicle and the surrounding ice. Therefore, at the edge of the gas vesicle where the ribs run parallel to the viewing direction, the outline of the particle appeared darker than the ice, whereas in the central region the gascontaining hollow part of the structure was lighter than the surrounding ice. The hollow structure of the gas vesicle was not only the reason for its good contrast, but also seemed to be the reason for its extreme sensitivity to irradiation by electrons; the ribs vanished after an irradiation of about 10 electrons per $\AA^{2}$. Nevertheless, the good contrast and conservation of this gas vesicle with a diameter of about $100 \mathrm{~nm}$ made it possible to identify the positions of single ribs.

As the rib structure on the upper and lower surfaces produced roughly the same contrast, it was expected that moiré patterns would be formed by superposition of the two lattices, depending on the viewing angle. These moiré patterns could be recognized in images of many investigated gas vesicles and can, in fact, be used to decide whether the ribs form a helix or a stack of 


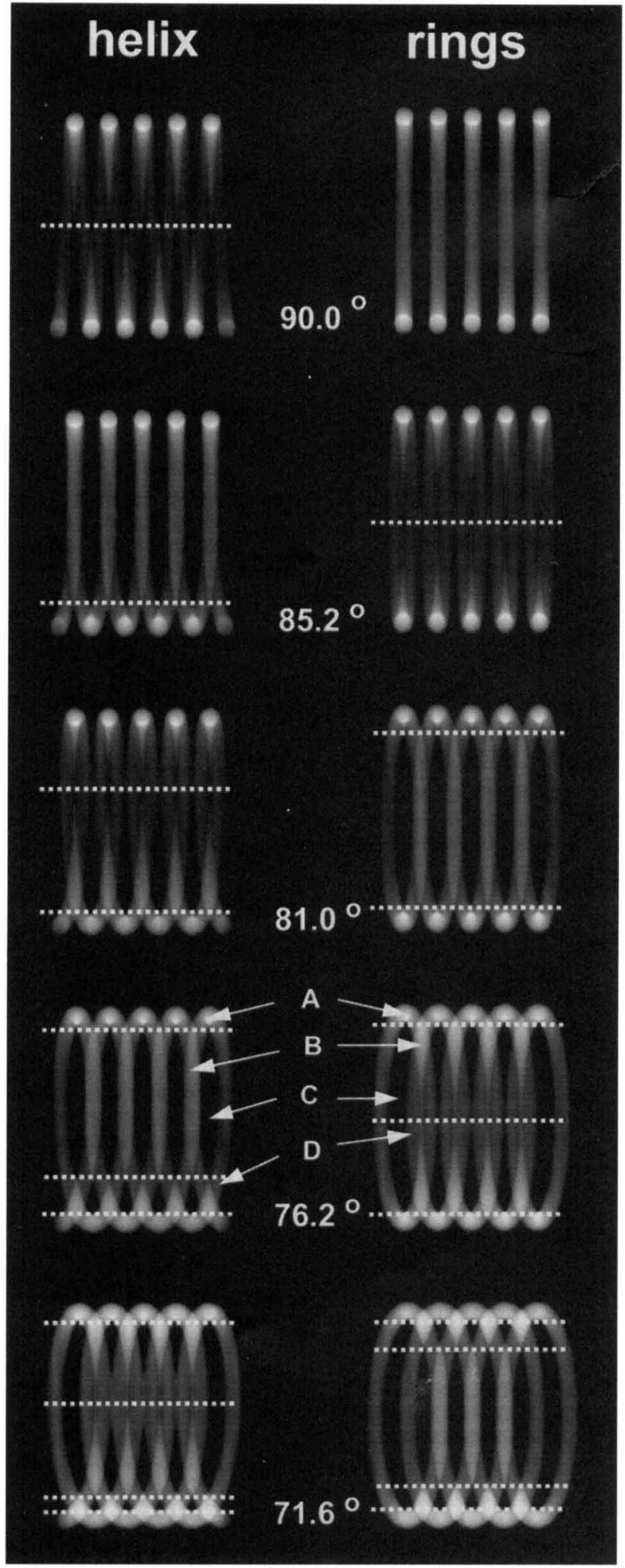

Fig. 6. Comparison of moiré patterns produced by tilting and projecting a helix and a stack of circular rings. The diameter of model $/$ distance of ribs $=6$, projection angles $90.0^{\circ}, 85.2^{\circ}, 81.0^{\circ}$, $76.2^{\circ}$ and $71.6^{\circ}$. The dashed lines indicate the positions of the extinction stripes in the moire patterns. A, light areas due to integrated density along the projection axis; $B$, areas where two loops or ellipses are superimposed; C, empty areas; D, areas containing only a single loop or ellipse. hoops. Due to the background noise, these features were not clearly visible in the original images, but they could be enhanced by image processing. The areas of the images marked with a dashed line in Figs $4(a)$ and 5(a) were window-filtered using the strongest reflections of their power spectra. The resulting images are shown in Figs 4(b) and 5(b). To adapt the images better to the perceptivity of the human eye, the image contrast was reversed so that the protein appears lighter than the ice. Obviously, the visibility of the ribs varies within the areas: in Fig. 4(b) there is one, and in Fig. 5(b) there are three stripes parallel to the particle's long axis where the ribs become faint (indicated by the arrows). These are areas in which the rib structures of both surfaces are shifted by half a period, as expected for such a moiré pattern. Across these regions the ribbed pattern jumps by half a period. Moreover, at the edge of the gas vesicle there is a series of bright spots: those at the upper edge are in line with the ribs whereas those at the lower edge are located halfway between the ribs.

The question of whether these images are projections of a helix or a stack of rings can, in principle, be answered from the distribution of moiré extinction stripes: these must be asymmetric in the case of a helix, and symmetric for stacked rings. Because of the small ratio of the rib distance to the vesicle diameter, the moire stripes are not easily recognizable in all cases, and those that are close to the edge of the particle are particularly difficult to see. We therefore made simulations of both cases and compared them with the processed images.

Simulations of helices and stacked hoops. Fig. 6 shows a comparison of projections of a helix and a stack of circular rings. At a projection angle of $90^{\circ}$ to the long axis, a helix appears as a sine function (in our case much like a zigzag line), whereas a stack of rings is projected into a set of parallel lines. At decreasing angles, the projection of a full helical turn forms a loop, while that of a ring forms an ellipse. Depending on the projection angle and the ratio of the diameter of the helix/rings to the distance between the helical turns (pitch) or rings and the projection angle, the projections of different loops/ellipses overlap or cross each other (or they do not touch at all for angles close to $90^{\circ}$ ). Loops cross themselves once and can cross increasing numbers of other loops as the tilt angle is decreased. The projection of rings looks similar despite the fact that the ellipses do not cross themselves. Looking at the grey levels of the projections in Fig. 6 one may differentiate between four types of areas: (A) areas which are lightest, because of integrated density along the projection axis; (B) areas where two loops/ellipses are superimposed; (C) empty areas and (D) areas containing only one loop/ellipse.

Referring to the moire patterns in Figs 4 and 5, (B) and (C) above correspond to areas where the rib structures are visible, while they are smeared in the area corresponding to $(\mathrm{D})$. The dashed lines in Fig. 6 indicate the position of the extinction stripes in all projections. The main difference between the projection of a helix and a stack of rings is that the moire pattern is asymmetric to 
the axis in the case of a helix, whereas it is symmetric for the projection of rings.

Figs $4(\mathrm{c})$ and $5(\mathrm{c})$ show projections of a helical model with parameters similar to those of the gas vesicle, with a value of 22.6 for the ratio of the diameter of the particle to the distance between ribs. In Fig. 4 (c), the model was projected at an angle of $88.1^{\circ}$, at which angle the different loops do not yet touch. The projection angle in Fig. $5(\mathrm{c})$ is $87.0^{\circ}$, which results in two overlapping neighbouring loops. The helical model simulations (Figs $4 \mathrm{c}$ and $5 \mathrm{c}$ ) agree so well with the images of the gas vesicle after image enhancement (Figs $4 b$ and $5 b$ ), that even the position of single loops could be identified. The dashed lines in Figs 4(b) and 5(b) indicate the positions of such a loop. From this result we conclude that the ribs of gas vesicles form a helix.

\section{DISCUSSION}

\section{Localization of the genes responsible for different gas vesicle shapes}

Transformation experiments and electron microscopy of isolated gas vesicles were performed to determine if chimeric gas vesicles (i.e. ones in which the gene products involved in gas vesicle assembly derive from two different vac regions) are produced, and to localize the gene(s) responsible for the different gas vesicle shapes. The complementation of the c-gvpE-M and c-gvpACNO genes of the c-vac region led to the synthesis of cGvpA and cylindrical gas vesicles in transformants (cE-M/cA-OI), implying that the c-gvp gene products were functional in Hf. volcanii and that complementation experiments were possible. However, expression of the c-g $\nu p A$ gene required an activating gene product from the c-g $\nu p E-M$ region because the transformant harbouring the $\mathrm{cA}-\mathrm{OI}$ construct by itself could not synthesize the c-GvpA protein. Subsequent transformation experiments assigned the c-gvpE gene product as the activator of the c-gvpA promoter (Krüger $\&$ Pfeifer, 1996; Krüger, 1996). The sequence of the c-gvpA promoter box A element ( $5^{\prime}$-GTTTTC-3') does not follow the archaeal consensus promoter sequence $\left({ }^{\mathrm{T}} / \mathrm{CTTA}^{\mathrm{T}} /{ }_{\mathrm{A}} \mathrm{G}\right.$ ) (Pfeifer et al., 1997; Hain et al., 1992), reflecting the fact that expression of the c-gvpA gene needs an activating gene product. In contrast, the p-gvpA promoter box A element (5'-CTTATG-3') completely matches the archaeal consensus promoter sequence and is active without the help of another $g \nu p$ gene product (Offner \& Pfeifer, 1995). The heterologous complementation in the $\mathrm{pD}-\mathrm{M} / \mathrm{cA}-\mathrm{OI}$ transformant did not lead to production of the c-GvpA protein, implying that activation of the $c-g v p A$ promoter must be specifically carried out by c-GvpE. The homologous gene product of the $\mathrm{p}$-vac region (if present) did not activate the c-gvpA promoter, indicating that in $H b$. salinarum PHH1 wild-type activation of the c-gvpA promoter cannot be achieved by the $\mathrm{p}-\mathrm{GvpE}$ protein.

As found for the c-vac region, complementation of the mc- $g \nu p D-M$ and the mc-g $\nu p A C N O$ transcription units of $\mathrm{Hf}$. mediterranei resulted in $\mathrm{Vac}^{+}$transformants. In contrast to the c-vac region, the mcA transformant synthesized the mc-GvpA protein, but only in small amounts. Thus, the mc-gvpA promoter is leaky, and subsequent transformation experiments indicated that strong mc-g $\nu p A$ gene expression depended on $\mathrm{mc}-\mathrm{GvpE}$ (Röder \& Pfeifer, 1996). Also in this case, the mc-gvpA box A element ( $5^{\prime}$-ATTTTG-5') (Englert et al., 1992a) does not follow the promoter box A consensus sequence (Hain et al., 1992). As the mc-gvpA transcription was leaky, the mc-vac subfragments were useful for heterologous complementation studies. Western analyses demonstrated that the amount of mc-GvpA was significantly higher in the $\mathrm{mcM}-\mathrm{O}, \mathrm{mcD}-\mathrm{M} / \mathrm{mcA}-\mathrm{O}$ and $\mathrm{p} \Delta \mathrm{A} / \mathrm{mcA}$ transformants than in the mcA transformant containing the mcA construct by itself (Englert et al., $1992 \mathrm{~b}$ and this report). In the case of the $\mathrm{p} \Delta \mathrm{A} / \mathrm{mcA}$ transformant, activation of mc-gvpA expression can apparently also be mediated by $\mathrm{p}-g \nu p D-M$ gene products.

Chimeric gas vesicles could be obtained with double transformants harbouring transcription units from different vac regions $(\mathrm{cE}-\mathrm{M} / \mathrm{pA}-\mathrm{O}, \mathrm{p} \Delta \mathrm{A} / \mathrm{cAII}, \mathrm{mcD}-$ $\mathrm{M} / \mathrm{pA}-\mathrm{O}, \mathrm{pD}-\mathrm{M} / \mathrm{mcA}-\mathrm{O}, \mathrm{p} \Delta \mathrm{A} / \mathrm{mcA})$. Obviously, the similarity of the gvp gene products of the three vac regions, which is between $50 \%$ and $97 \%$ (Englert et al., 1992a), is sufficient for replacing various Gvp proteins. This heterologous assembly of the gas vesicle envelope presupposes a certain structural flexibility of the assembly machinery. The gas vesicles of the $\mathrm{p} \Delta \mathrm{A} / \mathrm{cAII}$ and $\mathrm{p} \Delta \mathrm{A} / \mathrm{mcA}$ transformant were indeed chimeric, because the structural components GvpA and GvpC were derived from different vac regions. In addition, the mutated c-GvpA protein of the $\mathrm{p} \Delta \mathrm{A} / \mathrm{cAII}$ transformant (i.e. insertion of two amino acids, Met and Pro, at the Nterminus) led to gas vesicles, though with a slightly altered outline: the gas vesicles were wider than the wild-type gas vesicles, but the feature of the spindle shape was conserved.

However, homologous and heterologous complementation experiments demonstrated that some combinations of the transcription units were incompatible and did not result in gas vesicle synthesis: (i) in a regulatory manner, where the gene products of the p$g v p D-M$ region failed to activate the c- $g \nu p A$ promoter and consequently the gas vesicle formation was repressed and (ii) in a more structural manner, where the two additional amino acids at the $\mathrm{N}$-terminus of the c$\mathrm{GvpA}_{\text {mut }}$ protein hindered the gas vesicle formation. The c-GvpA $A_{\text {mut }}$ protein could not be used by the c$g \nu p C N O$ gene products for the formation of gas vesicles in the $\mathrm{Vac}^{-} \mathrm{pD}-\mathrm{M} / \mathrm{cA}-\mathrm{OII}$ or $\mathrm{cE}-\mathrm{M} / \mathrm{cA}-\mathrm{OII}$ transformants, whereas in the $\mathrm{p} \Delta \mathrm{A} / \mathrm{cAII}$ transformant, the $\mathrm{c}$ $g \nu p A_{\text {mut }}$ gene led to gas vesicles in combination with the p-gvpCNO genes.

Chimeric gas vesicles of the $\mathrm{pD}-\mathrm{M} / \mathrm{mcA}-\mathrm{O}$ and $\mathrm{mcD}-$ $\mathrm{M} / \mathrm{pA}-\mathrm{O}$ transformant were subjected to electron microscopy to investigate which gene product(s) determine the spindle-shaped, rather than cylindrical, 
morphology of the gas vesicles. Roughly half of the gas vesicles of the $\mathrm{pD}-\mathrm{M} / \mathrm{mcA}-\mathrm{O}$ transformant (expressing $\mathrm{mc}-\mathrm{GvpA}$ ) were spindle shaped, whereas the other half were cylindrical. The mc-GvpA protein usually forms the cylindrical gas vesicles of $H f$. mediterranei. In contrast, the $\mathrm{mcD}-\mathrm{M} / \mathrm{pA}-\mathrm{O}$ transformant (expressing the p-GrpA protein) formed mainly cylindrical gas vesicles, despite the fact that the $\mathrm{p}-\mathrm{GvpA}$ protein constitutes the spindle-shaped gas vesicles of $\mathrm{Hb}$. salinarum PHH1. Consequently, the amino acid sequence of $\mathrm{p}-\mathrm{GvpA}$, which differs from mc-GvpA by six amino acids (Englert $e t$ al., 1990), does not exclusively determine the spindle shape of the gas vesicles. More likely, one or more gene product(s) of the p-g $\nu p D-M$ gene cluster are also involved in the shape determination of the gas vesicles. However, a particular gvp gene cluster did not absolutely determine the shape of the respective wild-type gas vesicle, since the $\mathrm{pD}-\mathrm{M} /$ mcA-O transformant synthesized cylindrical and spindle-shaped gas vesicles in roughly equal quantities. All these aspects led to the conclusion that the difference in shape and length of the gas vesicles does not depend on a single protein. More likely, a dynamic equilibrium of two or more $g \nu p$ gene products is responsible for the determination of the shape during gas vesicle formation. In the case of the $\mathrm{pD}-\mathrm{M} / \mathrm{mcA}-\mathrm{O}$ transformant, this equilibrium was affected by the gene product(s) of the pgvpD-M genes that directed assembly of the gas vesicle envelope towards the spindle shape.

\section{Determination of the rib structure of the gas vesicle}

Transmission electron microscopy with frozen hydrated samples of intact gas vesicles was carried out to answer the old question of whether the ribs oriented perpendicular to the longitudinal axis of the gas vesicle are a stack of hoops or a helix. Walsby (1972) pointed out that this question might be solved by analysing the images of negatively stained collapsed gas vesicles. Superficially, a homogeneous appearance of the collapsed structure would then support the hoop model (Walsby, 1972). However, this question proved to be difficult to answer by analysing collapsed gas vesicles. The data presented in this study resulted from the analysis of intact gas vesicles that maintain their threedimensional structure in a frozen, hydrated state. In this case, the moire patterns produced by the images of the gas vesicle made it very likely that the ribs consisting of GvpA are formed by a helix of low pitch. Thus, the enlargement of the prestructures of the gas vesicles proceeds by the addition of GvpA to a helical structure, as implied by theoretical considerations discussed by Walsby (1994).

\section{ACKNOWLEDGEMENTS}

We wish to thank Wolfram Zillig for laboratory space at the Max-Planck-Institut für Biochemie in Martinsried. We thank Andrea Mayr, Simone Laska and Arnulf Kletzin for critical reading of this manuscript. The technical assistance of Ilka Dürr with electron microscopy of the chimeric gas vesicles is gratefully acknowledged. Mevinolin (Lovastatin) was a gen- erous gift of Merck, Sharp and Dohme. We are grateful to Wolfgang Baumeister, who kindly provided electron microscopy facilities for the investigation of the frozen hydrated gas vesicles. This work received financial support from the Deutsche Forschungsgemeinschaft (SFB 145/B6 and SFB 266/A2).

\section{REFERENCES}

Blaseio, U. \& Pfeifer, F. (1990). Transformation of Halobacterium halobium: development of vectors and investigation of gas vesicle synthesis. Proc Natl Acad Sci USA 87, 6772-6776.

Blaurock, A. E. \& Walsby, A. E. (1976). Crystalline structure of the gas vesicle wall from Anabaena flos-aquae. J Mol Biol 105, 183-199.

Cline, S. W., Schalkwyk, L. \& Doolittle, W. F. (1989). Transformation of the archaebacterium Halobacterium volcanii with genomic DNA. J Bacteriol 171, 4987-4991.

Damenval, T., Houmard, J., Guglielmi, G., Csiszar, K. \& Tandeau de Marsac, N. (1987). A developmentally regulated g $v p A B C$ operon is involved in the formation of gas vesicles in the cyanobacterium Calothrix 7601. Gene 54, 83-92.

Englert, C. \& Pfeifer, F. (1993). Analysis of gas-vesicle gene expression in Haloferax mediterranei reveals that GvpA and GvpC are both gas-vesicle structural proteins. J Biol Chem 268, 9329-9336.

Englert, C., Horne, M. \& Pfeifer, F. (1990). Expression of the major gas vesicle protein in the halophilic archaebacterium Haloferax mediterranei is modulated by salt. Mol Gen Genet 222, 225-232.

Englert, C., Krüger, K., Offner, S. \& Pfeifer, F. (1992a). Three different but related gene clusters encoding gas vesicles in halophilic archaea. J Mol Biol 227, 586-592.

Englert, C., Wanner, G. \& Pfeifer, F. (1992b). Functional analysis of the gas-vesicle gene cluster of the halophilic archaeon Haloferax mediterranei defines the vac-region boundary and suggests a regulatory role for the gvpD gene or its product. Mol Microbiol 6, 3543-3550.

Hain, J., Reiter, W.-D., Hüdepohl, U. \& Zillig, W. (1992). Elements of an archaeal promoter defined by mutational analysis. Nucleic Acids Res 20, 5423-5428.

Halladay, J., Jones, J., Lin, F., MacDonald, B. \& DasSarma, 5. (1993). The rightward gas-vesicle operon in Halobacterium plasmid pNRC100: identification of the $g \nu p A$ and $g \nu p C$ gene products by use of antibody probes and genetic analysis of the region downstream of g $\nu p C$. J Bacteriol 175, 684-692.

Hanahan, D. (1983). Studies on transformation of Escherichia coli with plasmids. $J$ Mol Biol 166, 557-580.

Hayes, P. K. \& Powell, R. S. (1995). The g $\nu p A / C$ cluster of Anabaena flos-aquae has multiple copies of a gene encoding GvpA. Arch Microbiol 164, 50-57.

Hayes, P. K., Buchholz, B. \& Walsby, A. E. (1992). Gas vesicles are strengthened by the outer-surface protein, GvpC. Arch Microbiol 157, 229-234.

Hegerl, R. (1996). The EM program package: a platform for image processing in biological electron microscopy. J Struct Biol 116, $30-34$.

Holmes, M. L., Nuttall, S. D. \& Dyall-Smith, M. L. (1991). Construction and use of halobacterial shuttle vectors and further studies on Haloferax DNA gyrase. J Bacteriol 12, 3807-3813.

Horne, M. \& Pfeifer, F. (1989). Expression of two gas vacuole protein genes in Halobacterium halobium. Mol Gen Genet 218, $437-444$. 
Horne, M., Englert, C. \& Pfeifer, F. (1988). Two genes encoding gas vacuole proteins in Halobacterium halobium. Mol Gen Genet 213, 459-464.

Horne, M., Englert, C., Wimmer, C. \& Pfeifer, F. (1991). A DNA region of $9 \mathrm{kbp}$ contains all genes necessary for gas vesicle synthesis in halophilic archaebacteria. Mol Microbiol 5, 11591174.

Jones, J. G., Young, D. C. \& DasSarma, S. (1991). Structure and organization of the gas-vesicle gene cluster on the Halobacterium balobium plasmid pNRC100. Gene 102, 117-122.

Kinsman, R. \& Hayes, P. K. (1997). Genes encoding proteins homologous to halobacterial Gvps $\mathrm{N}, \mathrm{J}, \mathrm{K}, \mathrm{F}$ and $\mathrm{L}$ are located downstream of gvpC in the cyanobacterium Anabaena flosaquae. DNA Seq 7, 97-106.

Kinsman, R., Walsby, A. E. \& Hayes, P. K. (1995). GvpCs with reduced numbers of repeating sequence elements bind to and strengthen cyanobacterial gas vesicles. Mol Microbiol 17, 147154.

Krantz, M. J. \& Ballou, C. E. (1973). Analysis of Halobacterium halobium gas vesicles. $J$ Bacteriol 3, 1058-1067.

Kruger, K. (1996). Untersuchungen zur Regulation der Gasvesikelsynthese in dem halophilen Archaeon Halobacterium salinarium PHH4. Dissertation, LMU München. Munich: Shaker Verlag.

Kruger, K. \& Pfeifer, F. (1996). Transcript analysis of the c-vac region, and differential synthesis of the two regulatory gas-vesicle proteins GvpD and GvpE in Halobacterium salinarium $\mathrm{PHH} 4$. $J$ Bacteriol 178, 4012-4019.

Lam, W. L. \& Doolittle, W. F. (1989). Shuttle vectors for the archaebacterium Halobacterium volcanii. Proc Natl Acad Sci USA 86, 5478-5482.

McMaster, T. J., Miles, M. J. \& Walsby, A. E. (1996). Direct observation of protein secondary structure in gas vesicles by atomic force microscopy. Biophys J 70, 2432-2436.

Mayr, A. \& Pfeifer, F. (1997). The characterization of the nvg $\nu p A C N O F G H$ gene cluster involved in gas vesicle formation in Natronobacterium vacuolatum. Arch Microbiol 168, 24-32.

Offner, S. \& Pfeifer, F. (1995). Complementation studies with the gas vesicle-encoding $\mathrm{p}$-vac region of Halobacterium salinarium PHH1 reveal a regulatory role for the p-gvpDE genes. Mol Microbiol 16, 9-19.

Offner, S., Wanner, G. \& Pfeifer, F. (1996). Functional studies of the gvpACNO operon of Halobacterium salinarium reveal that the GvpC protein shapes gas vesicles. J Bacteriol 178, 2071-2078.

Palmer, B. \& Marinus, M. (1994). The dam and $\mathrm{dcm}$ strains of Escherichia coli-a review. Gene 143, 1-12.

Pfeifer, F. \& Ghahraman, P. (1993). Plasmid pHH1 of Halo- bacterium salinarium: characterization of the replicon region, the gas-vesicle gene cluster and insertion elements. Mol Gen Genet 238, 193-200.

Pfeifer, F., Offner, S., Krüger, K., Ghahraman, P. \& Englert, C. (1994). Transformation of halophilic archaea and investigation of gas-vesicle synthesis. Syst Appl Microbiol 16, 569-577.

Pfeifer, F., Krüger, K., Röder, R., Mayr, A., Ziesche, S. \& Offner, S. (1997). Gas vesicle formation in halophilic archaea. Arch Microbiol 167, 259-268.

Röder, R. \& Pfeifer, F. (1996). Influence of salt on the transcription of the gas-vesicle genes of Haloferax mediterranei and identification of the endogenous transcriptional activator gene. Microbiology 142, 1715-1723.

Sambrook, J., Fritsch, E. F. \& Maniatis, T. (1989). Molecular Cloning: a Laboratory Manual, 2nd edn. Cold Spring Harbor, NY: Cold Spring Harbor Laboratory.

Schägger, H. \& von Jagow, G. (1987). Tricine-sodium dodecyl sulfate-polyacrylamide gel electrophoresis for separation of proteins in the range from 1 to $100 \mathrm{kDa}$. Anal Biochem 166, 368-379.

Simon, R. (1981). Morphology and protein composition of gas vesicles from wild type and gas vacuole deficient strains of Halobacterium salinarium strain 5. J Gen Microbiol 125, 103-111.

Stoeckenius, W. \& Kunau, W. H. (1968). Further characterization of particulate fractions from lysed cell envelopes of Halobacterium halobium and isolation of gas vacuole membrane. J Cell Biol 38, 337-357.

Surek, B., Pillay, B., Rdest, U., Bayreuther, K. \& Goebel, W. (1988). Evidence for two different gas vesicle proteins and genes in Halobacterium halobium. J Bacteriol 170, 1746-1751.

Ventosa, A. \& Oren, A. (1996). Halobacterium salinarum nom. corrig., a name to replace Halobacterium salinarium (ElazariVolcani) and to include Halobacterium halobium and Halobacterium cutirubrum. Int J Syst Bacteriol 46, 347.

Walker, J. E., Hayes, P. K. \& Walsby, A. E. (1984). Homology of gas vesicle proteins in cyanobacteria and halobacteria. J Gen Microbiol 130, 2709-2715.

Walsby, A. E. (1972). Structure and function of gas vacuoles. Bacteriol Rev 36, 1-32.

Walsby, A. E. (1994). Gas vesicles. Microbiol Rev 58, 94-144.

Walsby, A. E. \& Hayes, P. K. (1988). The minor cyanobacterial gas vesicle protein, GvpC, is attached to the outer surface of the gas vesicle. J Gen Microbiol 134, 2647-2657.

Received 2 September 1997; revised 16 January 1998; accepted 19 January 1998. 